\title{
4.製造販売後の安全性監視活動における リアルワールドデータ活用
}

宮崎 真，志藤 章仁，古田 英司，下寺 稔

MSD 株式会社 グローバル研究開発本部 ファーマコビジランス

<抄録 $>2018$ 年 4 月に施行された「医薬品の製造販売後の調査及び試験の実施の基準に 関する省令 (GPSP 省令) 」の改正により, 製造販売後の安全性監視活動においてリアルワー ルドデー夕の活用が認められた。そこで本稿では,「最良のエビデンスをつくる（サイエン ス)」「公衆衛生を保証する（レギュレーション）」「患者に対して良いことをする（フィー ドバック)」という安全性監視の 3 つの特徽が今回の改正においてどのように反映されて いるのか，企業の立場から考察した．

総じて, リアルワールドデータ活用を規定した今回の GPSP 省令改正は, 安全性監視が 持つ上記 3 つの特徴を活かし, その進展を促すものであった。一方で,リアルワールドデー 夕を活用した安全性監視活動の発展を更に促しうる点もいくつか明らかとなった。リサー チクエスチョンに打いては, 追加の安全性監視活動が必要となるリサーチクエスチョンの 考え方や通常の安全性監視活動等で得られる製造販売後情報をリサーチクエスチョン選択 に活用していく可能性について触れた。また, データ（データソース）に関連して，比較 調查実施前に行うべき調査の内容・時期等の例を紹介するとともに，それを可能とする基 礎的検討の拡充などに言及した，最後に，方法論においては記述的研究や疾患レジストリ 等, 方法論・データソースのバリエーションの更なる拡大等が海外との比較より課題とし て考えられた。また，これらの進展は，国際的な標準化そして国際競争力の発揮にも繋が るものと考えられた。

数多くの選択肢の中から最適解となるリサーチクエスチョン・データソース・方法論を 選択することは非常に難しいことであるが, これらの継続的な検討こそが, 最適な安全性 監視活動を可能とする経験の蓄積となり，結果，医薬品を使用する患者を守ることに繋が るものと信じ，各ステークホルダーが一体となり更なる検討が進められることに期待した い.

(薬剤疫学 2019；24(1)：31-39)

キーワード：リアルワールドデータ, 安全性監視, GPSP

\section{1. はじめに}

本稿においては，製造販売後の安全性監視活動 におけるリアルワールドデータの活用に関して企 業の立場から考察するが，そのためには筆者が考
える背景や適切な活用について，まず整理する必 要がある。 そこで本章では, 本論に該当する次章 に先立ち、これらの背景情報等を記述・整理す る.

著者連絡先：テ 102-8667 東京都千代田区九段北 1-13-12 北の丸スクエア MSD 株式会社グローバル研究開 発本部ファーマコビジランス安全対策部薬剂度学課 宮崎真

TEL：03-6272-0631 (直通), 03-6272-2025（部代表） FAX：03-6238-9086 E-mail : makoto.miyazaki @merck.com 


\section{1 製造販売後における規制下でのリアルワールド データを活用した活動とは}

本稿をまとめる背景となったのは間違いなく, 平成 30 年 4 月に施行された「医薬品の製造販売 後の調査及び試験の実施の基準に関する省令 (GPSP 省令) 」の改正である ${ }^{1)}$. 改正 GPSP 省令 では, 従来規定されていた使用成績調査（現在の 一般使用成績調查) ・特定使用成績調查・製造販売 後臨床試験に加え, 使用成績比較調査がデザイン として明記されると共に, 新たに製造販売後デー タベース調査が規定された。この「製造販売後 データベース」には，その定義により，いわゆる 診療報酬請求データベース・病院データベース・ 疾患レジストリが含まれる。すなわち, GPSP 省 令上これらリアルワールドデータを活用する道が 開けたのである.

一方で，表題にも掲げた安全性監視（ファーマ コビジランス）を考える。安全性監視とは「医薬 品の有害な作用または医薬品に関連する諸問題の 検出, 評価, 理解及び予防に関する科学と活動」 である ${ }^{2)}$ WHOにより定義されて以来その定 義・考えは, 少しずつではあるが定着してきてい るように感じられる。その認知を高める役割を果 たしたのは, 平成 25 年 3 月の「医薬品, 医薬部外 品, 化粧品及び医療機器の製造販売後安全管理の 基準に関する省令 (GVP 省令)」で定められた医 薬品リスク管理計画書 (RMP) であろう ${ }^{3)}$. RMP においては, 安全性監視活動として, 自発報告等 が該当する通常の安全性監視活動と, 市販直後調 査や GPSP 省令上の各調査・試験が該当する追加 の安全性監視活動が規定されている。

すなわち, GPSP 省令が規定するこれら製造販 売後調查等は, GPSP 省令に紐付く再審査制度に 基づく活動であると同時に，GVP 省令に基づく RMP における追加の安全性監視活動という性質 がある.これらを踏まえると, 改正 GPSP 省令に より認められたリアルワールドデータを活用した 製造販売後の活動とは, 追加の安全性監視活動と してのリアルワールドデータ活用に他ならない. このような観点により, 本稿では, 安全性監視活 動としてのリアルワールドデータの活用に注目
し，現状・課題を企業の視点より記述・検討する.

\section{2 安全性監視活動のゴール}

次に, 安全性監視活動のゴールについて考えて いきたい.すなわち「リアルワールドデータを追 加の安全性監視活動に活用することで, 何を達成 することができれば成功といえるのか」という視 点である.

安全性監視には 3 つの特徵があり, これらのバ ランスが良く保たれている環境において発展する といわれている ${ }^{4)}$. 以下, これら 3 つの特徵につ いて筆者の解釈も踏まえ簡単に紹介する.

・最良のエビデンスをつくる（サイエンス）

安全性監視活動とは, 基本的にはステップを経 て，あるいはエビデンスを重ねていく中で，その 都度適切な監視方法を検討・実施していくもので ある. 対象となる安全性上の懸念事項の内容等に も依存するところであるが，例えば自発報告およ び体系的なシグナル検出等のモニタリングを通じ て安全性上の懸念事項を明らかにしていき，その 内容・結果に応じて更に検証的な研究/調査を行 うといったステップが挙げられる.これらの各安 全性監視活動が結果としてさまざまなレベルのエ ビデンスを創ることに繋がるのだが, 各状況に応 じた適切な安全性監視活動の選択・計画・実施に は, 薬剤疫学的な視点をはじめとしてサイエンス の要素が必要となる.

・公衆衛生を保証する（レギュレーション）

公衆衛生とはWHOによると「組織された地域 社会の努力を通して, 疾病を予防し, 生命を延長 し, 身体的, 精神的機能の増進をはかる科学であ り技術」と定義されるものであるが5), 広くその 地域の公衆衛生を保証するものは「法制度・規制 (レギュレーション)」である。医薬品, 医療機器 等の品質, 有効性及び安全性の確保等に関する法 律 (薬機法), 医師法や前述の GVP 省令, GPSP 省令等を始めとしたさまざまな法制度・規制の中 で, 製薬産業・規制当局及び医療従事者等安全性 監視活動にかかる各ステークホルダーの役割・責 任が厳しく規定されている．アカデミア等で実施 される一般的な薬剤疫学的研究と性質を異とする 点が, この特徵により生じているものといえる. 


\section{・患者に対して良いことをする（フィードバック）}

これは，医療への貢献を通して患者へ寄与する ことを意味するものと考えられる。医療とはその 性質上常に不確実性を伴うため, その不確実性を 減らすことは，医療・患者いずれにもメリットの ある大きな課題といえる。すなわち, 安全性監視 活動の結果が医療にフィードバックされ，患者の 治療に貢献することで初めて, 真に価值のある安 全性監視活動となることを意味しているものと考 える，董を返すのであれば，医療にフィードバッ クされない，あるいは新たな知見へと繋がらない (不確実性を減らすことのない) 安全性監視活動 は, 活動としては不十分だと言っていることに他 ならない.

以上, これら 3 つの特徵を参考に, 今回の GPSP 省令改正により認められた製造販売後の安 全性監視活動におけるリアルワールドデータ活用 において, これら安全性監視の 3 つの特徴がどの ように反映されているのか, 次章において考察す る.

\section{2. 製造販売後の安全性監視活動におけるリアル ワールドデータ活用の現状・課題}

リアルワールドデータを活用した製造販売後の 安全性監視活動，すなわち製造販売後データベー ス調査は, 他の一般的な薬剂疫学的研究と同様に, 大きく「計画」「実施」「まとめ (公表)」の 3 つの 段階に分けることができる。しかしながら， 2018 年 4 月に実質的に開始となった製造販売後デー夕 ベース調查の多くは未だ「計画」の段階であり「実 施」「まとめ (公表)」に対する考察に限界がある こと, また製造販売後の安全性監視活動において も「計画」段階が非常に重要であることから, 本 章では計画段階, その中でも特に検討されている ベき必要がある、リサーチクエスチョン・データ (データソース)・方法論（研究デザイン）の 3 点 に注目し，製造販売後の安全性監視活動における リアルワールドデータの活用の現状・課題を考察 する.

\section{1 リサーチクエスチョン}

リアルワールドデータの適切な活用にはリサー
薬剂疫学 Jpn J Pharmacoepidemiol, 24(1) Jan 2019：33

チクエスチョンの適切な設定が必要不可欠であ る. 2018 年 1 月 23 日に独立行政法人医薬品医療 機器総合機構より示された「製造販売後調査等の 実施計画の策定に関する検討の進め方について」 に基づき，科学的に最適な手法を選択のうえ効率 的, 効果的な調査を実施することとして, 製造販 売後調査等もリサーチクエスチョン（具体的かつ 明確な調查の課題）を設定にしたうえで実施する こととなった ${ }^{6)}$. サイエンスの観点を強調するレ ギュレーションであり, 安全性監視の特徵を活か しつつ, その発展を促す変革といえよう。

しかしながら時間軸を考慮すると, この考え方 に一定の限界があるように思われる。承認申請ま でのエビデンスに基づき検討されたリサーチクエ スチョンが, そのタイミングにおける最善のもの であったとしても, 実際に製造販売後データベー ス調査を実施する時期（公開されている RMPに おいて実施時期が明記されているものは多くはな いが, 販売開始から 2 年〜 7 年と幅広い状況であ る）においても最善のリサーチクエスチョンであ ろうか. いわゆる「5TOOs」7)が示すように, 安全 性情報は製造販売後に急激に増加するため, 製造 販売後において検討すべきリサーチクエスチョン も, 得られた新たなデータ・エビデンスに応じて 変化していくのではないか. この考え方に従うこ とで, RMP のコンセプト (医薬品の開発段階, 承 認審査時から製造販売後の全ての期間においてべ ネフィットとリスクの評価・見直しを行うことに より，明確な見通しを持った製造販売後の安全対 策を実施する)が更に達成できるように思われる.

また同様に, 追加の安全性監視活動が全ての医 薬品において必要であるのか, という根本的な問 いも存在する。実際に日本の現状を確認すると， GPSP 省令改正後に承認された多くの医薬品にお いて市販直後調査とは異なる追加の安全性監視活 動が記載されている。ここで, EUにおける状況 を簡単に紹介する。 EUにおいて承認された医薬 品の内, nationally authorized medicinesにおけ る RMP の状況は CMDh (Co-ordination group for Mutual recognition and Decentralised procedures-human）のホームページにおいて公開され 
34 企画/リアルワールドデータ活用による承認審査・安全性監視の進展・チャレンジ

ている ${ }^{8)} . \mathrm{CMDh}$ とは, 複数の $\mathrm{EU}$ 加盟国におい て承認された医薬品に関するPRAC（Pharmacovigilance Risk Assessment Committee）からの勧 告に対し，最終的な position を決定するための規 制グループである。 その公開情報によると, 2018 年 10 月更新時のデータにおいては, 450 の有効成 分の約 $10 \%$ において薬剤疫学的研究を含む追加 の安全性監視活動の実施が認められた。これは即 ち, 特別な追加の安全性監視活動を必要とするこ と無く, ベネフィットとリスクのバランスが良好 である医薬品が多数を占めることを意味してい る.このような医薬品においては特に, 承認申請 時までのデータに基づいて追加の安全性監視活動 が必要となるリサーチクエスチョンを, 製薬企業 の視点から具体的に見いだすことは非常に困難に 思われる. 日本においては, 前述のとおりおよそ 全ての医薬品において市販直後調査以外の追加の 安全性監視活動が実施されている状況を考慮する と, そのような中で選択されたリサーチクエス チョンが, 本当に追加の安全性監視活動が必要な 程度のものであったのか, その検証もまた今後期 待されるところであろう.

これらの状況は「承認申請時の審査において合 意した活動について製造販売後に実施のうえ, 再 審査申請を行う」という再審査制度の建て付けに 基づく限界である可能性が考えられる。しかしな がら, 追加の安全性監視活動の検討時期・内容に 制度上の柔軟な解釈・運用が可能となれば, 安全 性監視活動の発展に向けた次の一歩となろう。ま た, 安全性監視が持つ特徵の一つであるフィード バックという観点でも同様である。例えば, 医 療・患者が必要とするデー夕は製造販売直後と製 造販売数年経過後では大きく異なる. 追加の安全 性監視活動の検討時期・内容に制度上の柔軟な解 釈・運用がうまれることにより, その時々の医療 の求める新たな知見に更に寄り添ったリサーチク エスチョンが設定可能になるだろう.

\section{2 データ（データソース）}

レギュレーションという観点では, 2017 年 6 月 9 日に示された「製造販売後の医薬品安全性監視 における医療情報データベースの利用に関する基
本的考え方について」において ${ }^{9)}$, データベース の選択に際し, 集積されているデータの期間, 調 査対象となる集団の例数ならびに集団の特徽, 追 跡可能性, 調查可能な医薬品の範囲, 調査可能な 有害事象およびデー夕の入手手続き等のデー夕 ベースの特徴について, あらかじめ十分な調査を 行うことと記述されている。 これらの項目には製 造販売後においてのみ十分な調查が可能となるも のがある. 例えば, 調査対象となる集団の例数・ 特徵については, 承認申請時において一定の予測 は可能であっても, 実際の挙動は製造販売後での み明らかとなる。そのために行われる製造販売後 における活動が「フィージビリティ調査」である. フィージビリティ調査は, FDAの Sentinel Initiative においても採用されている ${ }^{10)}$.

一方で, 前述の「あらかじめ十分な調查を行う べき項目」に関連して，特に比較対照群にかかる フィージビリティ調查の考え方が他のレギュレー ションと異なる可能性がある. 例えばFDAの Sentinel Initiative においては, 適切な比較対照群 が設定可能であるかフィージビリティ調査の中で 比較対照群における患者集団の例数 - 特徵等の確 認, 場合によってはアウトカムの粗集計も行われ る ${ }^{11)}$ 。このようにFDAにおいては比較対照群を 設定した活動に対して綿密な検討プロセスを選択 しているが, レギュレーションとしての意思決定 にも用いられることを考えると妥当とも思われ る. 製造販売後データベース調査もまた, その結 果が公表され, 添付文書改訂に用いられ, 医療・ 患者にフィードバックされることが期待される. これらをふまえると, 適切な比較対照群が設定で きるか否かという命題は, 製造販売後データベー ス調査においてもフィージビリティ調査において 合わせて確認すべき項目と考える.

以上の考察をふまえると, 製造販売後デー夕 ベース調査に向けたプロセスは図1のようになる ものと考えられる. 各調査活動の時期・内容に関 しては,リサーチクエスチョンや製品・疾患の特 性等により変動するが, ステップを踏み製造販売 後データベース調査上の各項目を明らかにしてい くアプローチは間違いないものであろう，MID- 
薬剂疫学 Jpn J Pharmacoepidemiol, 24(1) Jan 2019：35

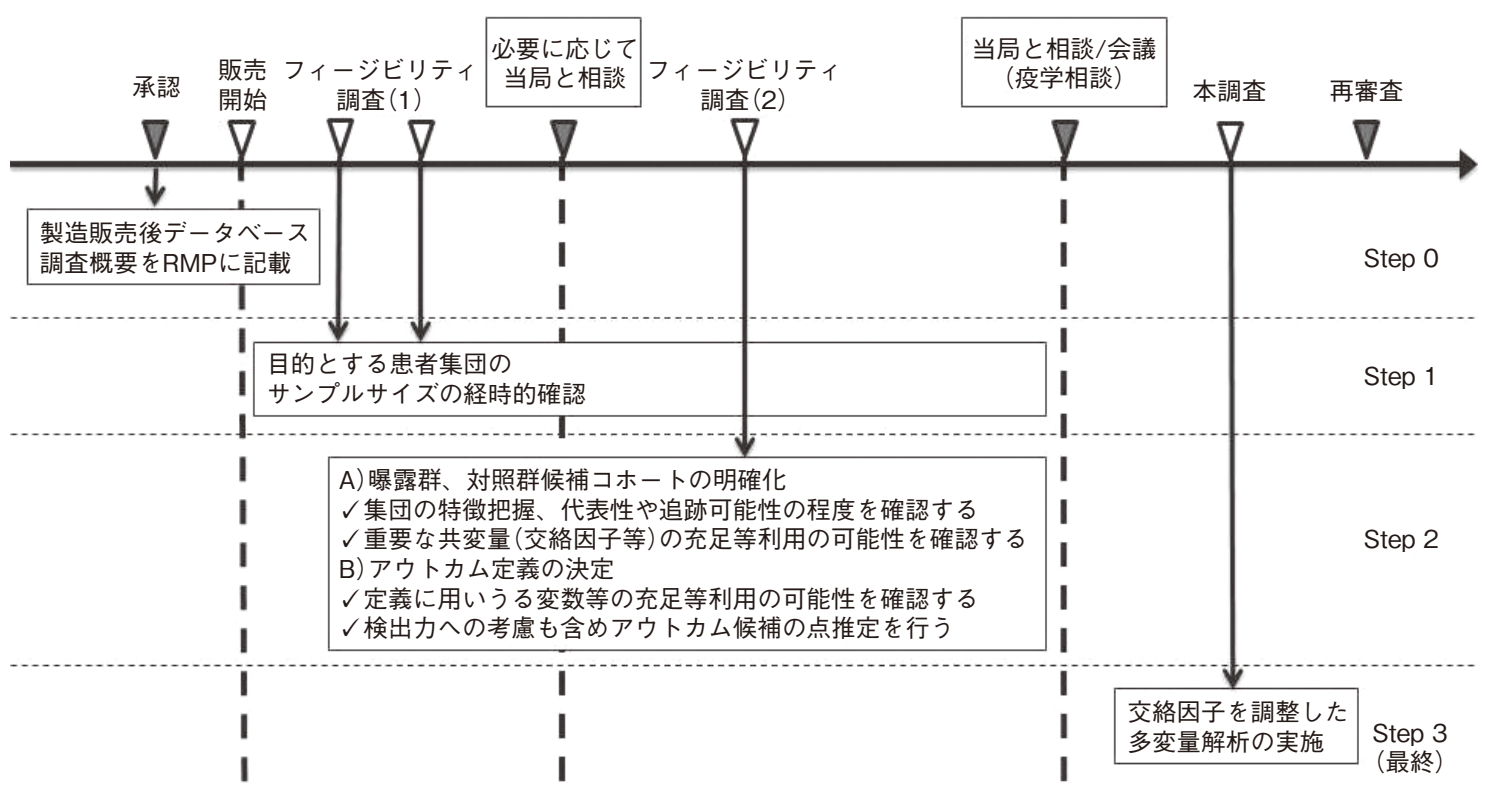

※なお、横軸は時間軸を示しているが、その間隔は実施時期を示すものではない

図 1 想定される製造販売後データベース調査に向けたプロセス

$\mathrm{NET}^{\circledR}$ においては基礎的検討という枠組にて フィージビリティ調査の一部を実施可能である が12， 上記プロセスにおける調査項目の全てを本 契約前に確認できるものではないため, 基礎的検 討の範囲拡大もまた期待されるところである。な お, アウトカムの妥当性もまた非常に重要な点で あるが, 詳細は日本薬剤疫学会におけるバリデー ションタスクフォースの報告書等を参照頂きた $\iota^{13)}$.

フィードバックという観点でも同様である。世 の中に「完璧なデータベース」は存在せず, デー タベース研究の結果解釈には限界が伴うものであ る. その限界の理解には, 薬剂疫学的な専門性が 通常必要であり, 他の専門領域の医療従事者ある いは国民に，その結果を適切に説明していくこと は必ずしも簡単なことではない. だからこそ，製 造販売後データベース調査を通じて誤解をうまぬ よう，特に比較対照群を設定した検証的な調査を 実施する場合においては，フィージビリティ調査 等を介し, 一つひとつの限界の可能性に対し数值 的な説明が可能となるような質の高い研究を展開
していくべきだと考える.

\section{3 方法論（研究デザイン）}

ここでいう方法論（研究デザイン）とは, 安全 性監視活動としての方法論と捉えて頂きたい. 安 全性監視活動の方法論に関してはICH E2E ガイ ドライン「医薬品安全性監視の計画」の別添にお いて紹介されている ${ }^{14)}$. すなわち受動的サーベイ ランス, 自発報告の強化, 積極的サーベイランス, 比較観察研究, 標的臨床研究, そして記述的研究： 疾病の自然史（Natural history of disease）や医薬 品使用実態研究 (Drug utilization study) である. これらの安全性監視方法が適切なタイミングで適 切な目的に対し用いられることで, 安全性監視活 動が適切に機能することを鑑みると，そのバリ エーションを広げた GPSP 省令はその発展をサ ポートするものであろう。

ここでは EMA における規制上の活動における バリエーションを紹介する。欧州においては 2006 年から EMA が主導し ENCePP（The European Network of Centres for Pharmacoepidemiology and Pharmacovigilance) というネットワーク 
を構築し，データベースや疾患レジストリ等リア ルワールドデータの情報提供 ${ }^{15)}$, リアルワールド データを用いた研究を含めた方法論をまとめる 等, 精力的な活動が行われている ${ }^{16)}$. その中の活 動の一つとして, リスク管理の一環として実施す る薬剤疫学的研究の登録制度 (ENCePP EU PAS Register）がある ${ }^{17)}$ 。それによると 2017 年 7 月時 点で登録されている 1,145 の研究で最も多いデザ インはリスク評価 (569 件) であったが, その次に 多いデザインは使用実態研究（378 件）となって いる ${ }^{18)}$. 続いて有効性の評価, 疾患の疫学等幅広 いデザインが登録されている，なお，データベー スの種類で見ると, 病院データベースや診療報酬 データベースとは異なる種類のデータベース（例 えば疾患レジストリ, 処方調剤データベースなど） の活用も認められた。

では GPSP 省令改正後に公開された RMP にお ける追加の安全性監視活動はどのように変容した のか. 系統的に確認するのは未だ難しい状況では あるが，一般使用成績調查（あるいは特定使用成 績調査), 比較観察研究デザインの製造販売後デー タベース調查, 治験からの延長を示唆する臨床試 験の 3 種類が多数を占め, また疾患レジストリの 活用は確認する事ができなかった．EMAにおけ る状況と比較すると, デザインとデータソースの バリエーションという点では必ずしも十分ではな いように思われる. 特に, ICH E2E ガイドライン 上の疾病の自然史や医薬品使用実態研究に注目し たい，例えば，適正使用状況等の評価を目的とし た製造販売後データベース調査は医薬品使用実態 研究に該当する可能性があるが，この様な活動は 追加の安全性監視活動として更に広く実施されて も良いのではないだろうか.もしも GPSP 省令 の中で方法論（デザイン）を限定・制限しうる状 況になっていることが適切な活動の選択を阻害し ているのであれば，今後検討すべき点の一つと言 うことができよう。

安全性監視の原点は「監視」すなわち「視るこ と」である，その点に立ち返って考えるのであれ ば，必要なサンプルサイズの集積を待ち統計的有 意性を評価する検証的な活動に必ずしも限定され
るべきではなく, 適切なタイミングでの情報提供 は，それが仮に記述的なデータであっても，医療・ 患者に貢献しうる点は考慮しなければならない. 医療従事者が目の前にいる患者に対し適切な治療 方針を検討できるように，疾病理解を促進するよ うなフィードバックもまた意味があろう。この点 においては，通常の安全性監視活動を規定する GVP 省令と GPSP 省令との役割あるいは建て付 けの整理というレギュレーションの観点もまた課 題の一つである可能性がある.

\section{3.まとめ}

製造販売後の安全性監視活動におけるリアル ワールドデータの活用の現状・課題を企業の立場 から考察してきたが，リアルワールドデータ活用 を規定した今回の GPSP 省令改正は,「最良のエ ビデンスをつくる (サイエンス)」「公衆衛生を保 証する（レギュレーション）」「患者に対して良い ことをする(フィードバック)」という安全性監視 が持つ 3 つの特徵を活かし, その進展を促すもの であった，すなわち, 改正 GPSP 省令および関連 の法規制のコンセプトに従い安全性監視活動を考 えていくことの重要性を改めて認識する機会に なったといえよう。もちろんそれは, リアルワー ルドデータの活用を視野にいれて検討することに ほかならない。

しかしながら一方で，リサーチクエスチョン・ データ (データソース)・方法論（研究デザイン） の 3 軸の考察においては, リアルワールドデータ を活用した安全性監視活動の発展を更に促しうる 点もいくつか明らかとなった（表 1). 端的には, リサーチクエスチョンの選択, 追加の安全性監視 活動の検討時期や方法論の選択, 実施に至るまで のプロセスに更なるフレキシビリティが生まれる ことへの期待とまとめることができよう。ただ し, これらはサイエンスとして適切であり, かつ レギュレーションが認めるものであり，そして実 施可能である必要があり, 各ステークホルダーが 一体となった十分な検討が必要であることはいう までもない.

また，前章における海外の状況との比較結果が 
薬剂疫学 Jpn J Pharmacoepidemiol, 24(1) Jan 2019:37

表 1 製造販売後の安全性監視活動におけるリアルワールドデータの活用の現状・課題：まとめ

\begin{tabular}{|c|c|c|c|}
\hline 検討項目 & 現状 & 課題 & 参考 \\
\hline \multirow[t]{2}{*}{$\begin{array}{l}\text { リサーチ } \\
\text { クエスチョン }\end{array}$} & $\begin{array}{l}\text { 承認申請までの治験等データに } \\
\text { 基づき決定される }\end{array}$ & $\begin{array}{l}\text { 通常の安全性監視活動等製造販 } \\
\text { 売後情報のリサーサーチクスチョ } \\
\text { ン選択への活用 }\end{array}$ & $\begin{array}{l}\text { “5 TOOs”に代表されるとおり, } \\
\text { 安全性情報は市販後に急激に増 } \\
\text { 加する }\end{array}$ \\
\hline & $\begin{array}{l}\text { 多くの医薬品において追加の } \\
\mathrm{PVP} \text { が必要となるリサーチク } \\
\text { エスチョンが存している }\end{array}$ & $\begin{array}{l}\text { 追加の安全性監視活動が必要と } \\
\text { なるリサーチクエスチョンの考 } \\
\text { え方 }\end{array}$ & $\begin{array}{l}\mathrm{EU} \text { 加盟国において承認された } \\
\text { 医薬品において, 追加の安全性 } \\
\text { 監視活動は } 10 \% \text { 程度 }\end{array}$ \\
\hline $\begin{array}{l}\text { データ } \\
(\text { データソース })\end{array}$ & $\begin{array}{l}\text { データベースの選択に際し, あ } \\
\text { らかじめ十分な調査を行うべき } \\
\text { 項目が定められている }\end{array}$ & $\begin{array}{l}\text { あらかじめ行うべき十分な調査 } \\
\text { の内容·時期等の更なる明確化, } \\
\text { また, それを可能とする基礎的 } \\
\text { 検討 }\end{array}$ & $\begin{array}{l}\text { FDA の Sentinel Initiative にお } \\
\text { いては, 比較群を含め透明性の } \\
\text { あるフィージビリテイ調査が行 } \\
\text { われる }\end{array}$ \\
\hline 方法論 & $\begin{array}{l}\text { GPSP 省令等にて調査目的・ } \\
\text { データソース・デザイン等が規 } \\
\text { 定されている }\end{array}$ & $\begin{array}{l}\text { 記述的研究や疾患レジストリ } \\
\text { 等, 方法論・データソースのバ } \\
\text { リエーションの更なる拡大 }\end{array}$ & $\begin{array}{l}\text { ENCePP EU PAS Register の } \\
\text { データにおいて, } 30 \% \text { 程度は使 } \\
\text { 用実態研究であり, また疾患レ } \\
\text { ジストリ等幅広いデータソース } \\
\text { が用いられている }\end{array}$ \\
\hline
\end{tabular}

示すとおり，これらの更なる進展は安全性監視の 国際的な標準化に寄与するものである点にも触れ ておきたい. 医薬品の承認状況やリアルワールド データの状況等各国間の差異には留意すべきであ るものの, 医薬品開発プログラムにおける国際化 が進む中においては，日本におけるその安全性監 視活動が国際的にも貢献する活動であるのか, そ の必要性が国際的にも自明なものであるのか, こ のような視点もまた重要なものと考える. 言い換 えるのであれば, そのリサーチクエスチョン・デー タソース・方法論の選択が国際的な観点において 適切であり，その結果が国際的にも受け入れられ る活動であるのか，といえよう。なお，これら国 際化は, 結果として日本の国際競争力を発揮する ことにも繋がるものと考えている.

「患者に対して良いことをする」という安全性 監視の意義を捉えながら, 数多くの選択肢の中か ら最適解となるリサーチクエスチョン・データ ソース・方法論を選択することは非常に難しいこ とである。 また，その最適解もまたサイエンス・ テクノロジーの進歩等により変化していくもので あろう。しかしながら，これらの継続的な検討こ そが, 最適な安全性監視活動を可能とする経験の 蓄積となり, 結果, 医薬品を使用する患者を守る
ことに繋がるものと信じている，本稿は，製造販 売後の安全性監視におけるリアルワールドデータ 活用という大きなテーマの中での一部の考察では あったが，より良き活用に向けた更なる検討・議 論のきっかけの一つとなれば幸いである.

\section{文献}

1）厚生労働省. 医薬品の製造販売後の調查及び試験の 実施の基準に関する省令等の一部を改正する省令. 厚生労働省令第 116 号平成 29 年 10 月 26 日. [https://www.pmda.go.jp/files/000220766.pdf (accessed on 2018-12-17) ]

2) WHO. Pharmacovigilance. [https://www.who.int/ medicines/areas/quality_safety/safety_efficacy/ pharmvigi/en/ (accessed on 2018-12-17) ].

3）厚生労働省. 医薬品, 医薬部外品, 化粧品及び医療 機器の製造販売後安全管理の基準に関する省令及び 医薬品の製造販売後の調查及び試験の実施の基準に 関する省令の一部を改正する省令の施行について. 厚生労働省医薬食品局長. 薬食発 0311 第 7 号 平成 25 年 3 月 11 日. [http://www.pmda.go.jp/files/ 000143723.pdf (accessed on 2018-12-17) ]

4) Meyboom RHB, Leufkens HGM, van Puijenbroek EP. Thoughts on Pharmacovigilance in the Future : There Are More Weber-Effects. In : Ralph Edwards et al. Eds. Pharmacovigilance : Critique and Ways Forward. Adis, 2017. p. 115-20．［野村香織(監 修, 翻訳), ファーマコビジランス＆リスクマネジ 
メント研究会 (編). ファーマコビジランス論評, そ して進展. じほう。2018]

5) Acheson D. Public Health in England : The Report of the Committee of Inquiry into the Future Development to the Public Health Function. London : HMSO, 1988.

6) 独立行政法人医薬品医療機器総合機構, 製造販売後 調査等の実施計画の策定に関する検討の進め方につ いて. 平成 30 年 1 月 23 日. [https://www.pmda. go. jp/files/000222291. pdf (accessed on 2018-1217) ]

7) Rogers AS. Adverse drug events : identification and attribution. Drug Intell Clin Pharm. 1987 ; 21 (11) : 915-20.

8) Co-ordination Group for Mutual Recognition and Decentralised Procedures-Human. Heads of Medicines Agencies: RMP. [http://www.hma.eu/464. html (accessed on 2018-12-17)].

9）厚生労働省. 製造販売後の医薬品安全性監視におけ る医療情報データベースの利用に関する基本的考え 方について. 厚生労働省医薬 ·生活衛生局医薬品審 査管理課長・安全対策課長. 薬生薬審発 0609 第 8 号薬生安発 0609 第 4 号平成 29 年 6 月 9 日. [https://www.pmda.go.jp/files/000218531.pdf（accessed on 2018-12-17) ]

10) Food and Drug Administration. Active Risk Identification and Analysis (ARIA), Sentinel Initiative. [https://www.sentinelinitiative.org/active-riskidentification-and-analysis-aria (accessed on 201812-17)].

11) Food and Drug Administration. Warfarin and GI Bleed, Intracerebral Hemorrhage, Sentinel Initiative. [https://www.sentinelinitiative.org/drugs/ assessments/warfarin-and-gi-bleed-intracerebralhemorrhage (accessed on 2018-12-17)].

12) 独立行政法人医薬品医療機器総合機構. MID-NET
の利活用の初期段階における基礎的検討の実施要綱 について、薬機発第 0629050 号平成 30 年 6 月 29 日. [https://www.pmda.go.jp/files/000222796.pdf (accessed on 2018-12-17)].

13）岩上将夫, 青木事成, 赤沢学ら.「日本における傷病 名を中心とするレセプト情報から得られる指標のバ リデーションに関するタスクフォース」報告書. [http://www.jspe.jp/committee/pdf/validationtrr 120180528.pdf (accessed on 2018-12-17)]

14）厚生労働省. 医薬品安全性監視の計画について。厚 生労働省医薬食品局審査管理課長・安全対策課長. 薬食審査発第 0916001 号 薬食安発第 0916001 号平 成 17 年 9 月 16 日. [https://www.pmda.go.jp/ files/000156059.pdf (accessed on 2018-12-17) ]

15) European Network of Centres for Pharmacoepidemiology and Pharmacovigilance. ENCePP Resources Database. [http://www. encepp. eu/ encepp/resourcesDatabase.jsp (accessed on 201812-17) ]

16) European Network of Centres for Pharmacoepidemiology and Pharmacovigilance. ENCePP Guide on Methodological Standards in Pharmacoepidemiology. [http://www.encepp.eu/standards_and_ guidances/methodologicalGuide.shtml (accessed on 2018-12-17)]

17) European Network of Centres for Pharmacoepidemiology and Pharmacovigilance. EU PAS Register. [http://www.encepp.eu/encepp_studies/in dexRegister.shtml (accessed on 2018-12-17) ]

18) Kurz X, Perez-Gutthann S; ENCePP Steering Group. Strengthening standards, transparency, and collaboration to support medicine evaluation: Ten years of the European Network of Centres for Pharmacoepidemiology and Pharmacovigilance (ENCePP). Pharmacoepidemiol Drug Saf. $2018 ; 27$ (3) : 245-52. 
薬剤疫学 Jpn J Pharmacoepidemiol, 24(1) Jan 2019: 39

Special Issue on "Progress and Challenge of Drug Development and Pharmacovigilance Through Utilization of Real World Data"

\title{
4. Utilization of Real World Data for Post-marketing Pharmacovigilance Activity
}

\author{
Makoto MIYAZAKI, Akihito SHITO, Eiji FURUTA, Minoru SHIMODERA \\ Pharmacoepidemiology, Japan Pharmacovigilance, MSD K. K., Japan
}

\begin{abstract}
$\langle$ Abstract $\rangle$
Good Post-Marketing Study Practice (GPSP) changed in April 2018, allows pharmaceutical companies to use a real-world data for pharmacovigilance activity. On the other hand, it is known that there are 3 major dimensions of pharmacovigilance: "Monitoring, vigilance, and science: building the best evidence", "Regulation, industry, and legal system : ensuring public health" and "Medicine, medicines, and uncertainty: doing good to patients". Therefore, in this article, we consider how the change of GPSP reflects on the 3 features of pharmacovigilance.

In general, it is thought that the change of GPSP contributes pharmacovigilance, considering the 3 features of pharmacovigilance. On the other hand, there are some points to improve pharmacovigilance system : 1) how a safety question for pharmacovigilance should be addressed, 2) how information of routine pharmacovigilance should contribute to a safety question to be addressed, 3) how a feasibility assessment (assessment of data source before conducting a formal comparative activity) should be conducted, and 4) a necessity of a variety of methodology and data sources such as descriptive studies and disease registry. These improvements will contribute to global standardization and give us global competence.

Overall, it is very difficult to consider the best safety question, data source and methodology from many options. However, it is thought that keep considering them in order to accumulate experiences is important for our ultimate goal, which is to help our patients. We expect more discussions among all the stakeholders together.

(Jpn J Pharmacoepidemiol 2019;24(1):31-39)
\end{abstract}

Keywords: real world data, pharmacovigilance, Good Post-Marketing Study Practice 